\title{
Women and the Radical Right: Exploring Gendered Differences in Vote Choice for Radical Right Parties in Europe
}

\author{
Michael A. Hansen
}

Politics, Philosophy, and Law Department at the University of Wisconsin - Parkside

hansenm@uwp.edu

\begin{abstract}
This article explores the role that gender differences played in vote choice for radical right parties in European countries from 2002-2014. In particular, the research agenda explores whether men and women differ in regards to the attitudinal variables that drive vote choice for a radical right party. Further, the empirical analysis tests whether predictors of radical right vote choice have differing substantive effects for women and men. Using fixed effects statistical models; the major findings are that men and women do differ statistically on one attitude that correlates highly with radical right vote choice (i.e. far right ideology), but not other important attitudes (anti-immigrant sentiment). Substantively, however, given the same attitudes as men, women have a significantly lower probability of translating extreme attitudes into vote choice for radical right parties.
\end{abstract}

\section{Keywords}

Gender Gap, Radical Right Voting, Radical Right Parties, Gender Gap in Voting, European Politics

\section{Frauen und die radikale Rechte: Geschlechterunterschiede bei der Wahl rechtsradikaler Parteien in Europa}

\author{
Zusammenfassung \\ Dieser Artikel erforscht die Rollevon Geschlechterunterschieden bei der Wahl rechtsradikaler Parteien in europäischen Ländern \\ im Zeitraum von 2002 bis 20I4. Insbesondere wird untersucht, ob Männer und Frauen sich hinsichtlich der Einstellungen, die \\ zur Wahl einer rechtsradikalen Partei führen, unterscheiden. Darüber hinaus überprüft die empirische Analyse, ob die Effekte \\ der Prädiktoren für die Wahl der radikalen Rechten bei Frauen und Männern variieren. Mit Hilfe statistischer Modelle werden \\ folgende Ergebnisse gefunden: Männer und Frauen unterscheiden sich statistisch hinsichtlich einer Einstellung, die hochgradig \\ mit der Wählerpräferenz für die radikale Rechte korreliert (nämlich rechter Ideologie), aber nicht bei anderen wichtigen \\ Einstellungen (wie immigrationsfeindlichen Stimmungen). Im Wesentlichen aber zeigt sich bei Frauen eine verglichen mit \\ Männern signifikant geringere Wahrscheinlichkeit, dass dieselben extremen Einstellungen auch zu einer Wahlentscheidung \\ für rechtsradikale Parteien führen.

\section{Schlüsselwörter} \\ Gender Gap, Wahl rechtsradikaler Parteien, Rechtsradikale Parteien, Gender Gap bei Wahlen, Europäische Politik
}

The author has declared that no competing interests exist. 


\section{Introduction}

Radical right parties in Europe have received a wealth of attention in the political parties' literature due to the potential threat that these parties pose to liberal democratic governance. Important areas of exploration related to the radical right include explanations for the emergence or existence of these parties (Kitschelt 1995, Mudde 2007), the substantive effects of radical right parties on the European political landscape (Howard 20IO, Mudde 2007, Hansen and Clemens 2019), how other political parties interact with the radical right (Norris 2005, Meguid 2005, Bale et al. 20I0, Howard 20I0, van Spanje 20IO), how the political opportunity structure impacts the success of these parties (Golder 2003, Hansen 2016), and how to define and categorize parties of the radical right (Kitschelt I995, Mudde 2007). One important area of inquiry explores the disparate ways in which gender plays a role in the success of these parties. In particular, the extent to which gender differences play a role in voting/support for radical right parties and their policies has received increased attention (Harteveld et al. 2015, Immerzeel et al. 20I5, Mayer 20I5, Spierings/Zaslove 2015, Harteveld/Ivarsflaten 2016, Erzeel/Ekaterina 20I7, Harteveld et al. 20I7, Spierings/Zaslove 20I7).

The literature has made tremendous strides in demonstrating that the gender gap in support for the radical right might not be related to a gender gap in a singular attitude. Further, important new studies demonstrate that previously uncovered mechanisms may explain women's hesitation to vote for radical right parties (Harteveld et al. 20I5, Harteveld/Ivarsflaten 20I6, Spierings/Zaslove 20I7). This research agenda seeks to provide a large-N, statistical test for gendered voting across a substantial period of time (2002-2014) in order to confirm these findings. In particular, this article investigates three aspects of gendered voting for the radical right throughout this time period in Europe.

First, the analysis will use bivariate models to investigate whether men and women hold the political attitudes that are most commonly associated with voting for radical right parties at the same rate. More concretely, this first exploration tests whether there really is a gender gap in theoretically relevant radical right attitudes. Second, the research agenda will empirically test whether gendered differences in voting for the radical right party across Europe can be explained by a difference in the importance that men and women place on attitudes when predicting vote choice. While it is relatively well known that men are more likely to cast a vote for radical right parties, it is less clear whether the smaller proportion of women that do decide to cast a vote for these parties do so for different reasons. Perhaps, the gender gap in voting could be explained by the fact that different attitudinal traits explain radical right vote choice for women and men. For example, it might be the case that far right ideological positioning leads men to vote for the radical right party, while anti-immigrant/nativist attitudes lead women to vote for the party. Lastly, if radical right vote choice for both women and men is correlated with the same attitudinal positions, it is important to explore whether these attitudinal positions have the same substantive impact on the probability of voting for the radical right party. The result might indicate that men and women are both affected by an attitude such as far right positioning, but it is worth testing whether the effect of political ideology on the probability of voting is substantively the same. Current research does not explore these three areas of inquiry simultaneously.

The empirical results indicate that men are not more likely to hold the most important political attitudes most commonly associated with voting radical right, with the exception of far right ideological positioning. Further, regarding the mechanisms that explain voting radical right, the variables that correlate with voting for the radical right are the same for women and men. However, the research agenda finds that although women and men are affected by the same variables, the substantive effect of these variables on men's voting behavior is substantially larger. The article provides some corroborating evidence for the theory that women may hold attitudes associated with the radical right, but women are far less likely to violate societal norms and translate those attitudes into a vote for a radical party.

\section{Gender Gap in Political Attitudes}

Gender gaps in political attitudes and participation have been studied in a number of different contexts and countries. For example, a study done in the U.S. by Kaufmann and Petrocik (1999) found that men and women differ on important attitudinal positions about government that are related to vote choice. The authors find the gender gap is caused partially by men's changing attitudes on issues of social welfare. The study concludes that while women have remained stable on political attitudes, men are becoming more conservative on several important positions. Since Kaufmann and Petrocik's (1999) study, several scholars have uncovered distinct mechanisms going beyond simple ideological shifts that explain gender gaps in attitudes.

Howell and Day (2000) demonstrate that different socio-demographic factors have varying effects on women and men. The authors find that while some factors such as education have a more liberalizing effect on women, other factors such as religiosity have a more conservatizing effect on men. Overall, the authors note that the gender gaps arise from both women's changing cultural role and their increasing autonomy from men. 
Kaufmann (2004) confirms this trend in her study, showing that women and men politicize their religious beliefs in very different ways. Further, Schlesinger and Heldman (200I) demonstrate that the gender gap in attitudes could also be a product of a difference in perceived opportunity gaps and perceived efficacy in government programs. When exploring the gender gap historically, Norrander and Wilcox (2008) find that the gender gap is not only a product of men becoming more conservative, but also the increased willingness of women to self-identify as liberal. Interestingly, Kellstedt et al. (20I0) find that even when women and men's political attitudes respond to changes in public policy in the same direction, men appear to be more responsive to policy change than are women when exploring the level of change in their attitudes.

Cross-nationally, similar trends have been found relative to the gender gap in political attitudes. Inglehart and Norris (2000), using the World Values Survey in the early I980s and the early to mid I990s, find that a traditional left-right ideological gender gap exists crossnationally. More recently, McEvoy (2016) uncovers that a gender gap persists in terms of attitudes in European Parliament (EP) elections, and finds a gendered attitudinal gap when exploring support for different types of European Union (EU) policies. However, the author points out that there is quite a bit of variation across the countries in the sample. For example, empirically there is only a very small gender gap in support for most liberal attitudes in Italy. In the European context, political attitudes have been studied most closely in terms of their relationship to specific political party vote choice.

\section{Gender Gap in Radical Right Voting}

The previous section solely explored the gendered differences in political attitudes. As stated earlier, scholars studying radical right vote choice have unanimously found a link between gender and voting for the radical right (Kitschelt 1995, Givens 2005, Norris 2005, van Spanje 20IO, van Heerden et al. 2014, Harteveld et al. 2015, Immerzeel et al. 2015, Mayer 2015, Spierings/Zaslove 2015, Harteveld/Ivarsflaten 2016, Erzeel/ Ekaterina 20I7, Harteveld et al. 20I7, Spierings/Zaslove 2017). Several of these authors have, through statistical testing, determined that there is a negative correlation between gender $(\mathrm{men}=\mathrm{O}$; women $=\mathrm{I})$ and vote choice for these parties. Men are more likely to vote for radical right parties, and the vote percentage is, on average, double for men what it is for women.

\subsection{Gender Gap in Radical Right Attitudes}

In regards to the political attitudes most associated with radical right vote choice, there is debate over whether a real gender gap in attitudes exists. Coffe (2OI3) argues that the gender gap in voting for the radical right can be explained away by looking at the difference between women and men on a few key socio-demographics and values on attitudinal positions. The author finds that when accounting for differences in views of immigrants there is the same probability of voting for a radical right party between women and men. Coffe (2OI3) concludes that women are much less likely to hold anti-immigrant and xenophobic attitudes. Further, the author finds that men also tend to vote for radical right parties in greater numbers due to concerns over job security and household finances. For Coffe (2OI3), a mix of anti-immigrant sentiment and concern over job security explains mens' vote for radical right parties.

Agreeing partially, Spierings and Zaslove (2017) argue that differences in populist attitudes explain the gender gap in voting for the radical right, and not a difference in anti-immigrant attitudes. Similarly, Immerzeel et al. (2015) tested radical right voting in I2 Western European countries using the 2010 European Values Study. The authors find when using bivariate "difference of means tests" that men and women differ in their probability to vote for a radical right party due to their holding different attitudes on several important nativist survey questions.

\subsection{Gender Gap in Attitude Salience}

In contrast, more recent studies argue that there is not a gender gap on the political attitudes most closely related to voting for the radical right party. Mayer (2015) finds that women and men hold fairly similar beliefs on the political attitudes that correlate with voting for the French National Front party. In addition, while exploring the gender gap in voting since 2012 , the author finds that there is no longer a gender gap at all. The main claim is that changing demographics, the change in immigration context, and National Front appeals to women have led women to choose the party at the same rate as men. Further, Erzeel and Ekaterina (2017) delved into the perceived closing of the gender gap in radical right support. The authors found that it does not appear as though radical right parties have moderated their message since the 1980s. However, the authors note that, at least in some countries, radical right parties actively engage and political involve women in some discussions related to women's policy concerns.

Similarly, Spierings and Zaslove (2015) call into question whether a significant gender gap currently exists regarding anti-immigrant attitudes. Instead, the authors argue that while women and men hold similar beliefs on several political attitudes, the genders weight those attitudes differently in their vote calculation. In addition, Harteveld et al. (2015) find that socio-cultural 
and attitudinal differences do not play a role in the gender gap in radical right vote choice. Instead, the authors argue that men simply consider the issues of the radical right to be more salient, and that the radical right might deter women for other reasons that go beyond the political party program. However, a clear test of the assertion is not provided. Finally, new research on motivation to control prejudice, which will be discussed in the final section of this discussion, finds that men and women do not differ on important political attitudes related to vote choice (Harteveld/Ivarsflaten 2016, Harteveld et al. 2017). The empirical section in this article seeks to test the assertions derived from these debates. Based on the most recent research, there are two hypotheses posited:

$H_{\text {Ia }}:$ On average, a gender gap does exist when it comes to political ideology, and men are further to the right on the ideological spectrum.

$H_{a b}$ : On the main attitudinal predictor of radical right vote choice, nativist attitudes, women do not differ in terms of holding anti-immigrant attitudes.

$H_{2}$ : The attitudes that predict radical right vote choice for men (far right ideological positioning and anti-immigrant attitudes) are the same attitudes that predict radical right vote choice for women.

\section{Gender and Controlling Prejudice (i.e. norm violation)}

Recent research on the gender gap in voting for radical right parties, or any extreme parties, is that the gender gap persists because women and men differ in their propensity to violate social norms. Broadly, Ivarsflaten et al. (20I0) argue that in Western European immigration politics debates, an anti-racism norm might exist. Positing a new way of thinking about measuring attitudes towards immigration, the authors develop a theoretical construct in which there are two types of individual measures for the anti-racism norm. In particular, there is an external motivation to control prejudice and not be perceived as racist, and an internal motivation to uphold unbiased views of racial groups. The study by Ivarsflaten et al. (2010) was conducted in Norway and the authors found that both types of the anti-racism norm were related to anti-immigrant attitudes.

How does the Ivarsflaten et al. (20I0) study on the anti-racism norm relate to gender and radical right voting? Harteveld and Ivarsflaten (2016) conducted a study that explored voting for the radical right British $\mathrm{Na}$ tional Party, Sweden Democrats, and Norwegian Progress Party in order to further investigate the connection. The authors find that women are more likely to vote for a radical right party if it has a "reputation shield." That is, women are less likely to vote for parties that are seen as too extreme, and more likely to cast a vote for a party that does not have a neo-Nazi past or current social stigma. The major takeaway is that women are more likely than men to be motivated to control prejudice, and that this internal motivation accounts for the gender gap in voting for radical right parties. Since radical right parties are caught up in conflicts related to discrimination and prejudice, women do not view these parties are a legitimate option in the electoral market. On the other hand, we know that across the board women when compared to men support radical right parties at much lower rates. Therefore, a large- $\mathrm{N}$ analysis is needed to fully explore the topic behind distinguishing between voting within the radical right party family.

A recent study on women's propensity to control prejudice is Harteveld et al. (2017). The study explored 28 European countries using the Comparative Study of Electoral Systems data between 1996-201I. The motivating theory was that gender socialization is different for women and men. In particular, the authors argue that there are two gendered differences in the sociopsychological literature: I.) Men have a generally lower sensitivity to social cues, which means they are more likely to vote for stigmatized parties. 2.) In comparison, women have a greater concern with social harmony, which means they are less likely to vote for extreme parties (Harteveld et al. 20I7, 3-6). Harteveld et al.'s (2017) major finding was that men are more likely to vote for parties that are socially stigmatized or ideologically extreme: a finding that is strong even when controlling for similar socio-demographics and political attitudes. In sum, women are far less likely to violate societal norms and cast a vote for far left and far right parties. Given this most recent research, one might expect that the effects of variables correlated with radical right vote choice would be different for women and men. Therefore, $\mathrm{H}_{3}$ is posited below:

$\mathrm{H}_{3}$ : For women, the substantive effects from independent variables that increase the probability of voting for the radical right party are smaller than the substantive effects for men.

\section{Methodology}

\subsection{Data}

The data used for the empirical analysis is the biennial European Social Survey (ESS) from 2002-2014 (ESS 2017). ${ }^{I}$ The ESS is an ongoing study measuring socio-

I The 2016 European Social Survey was not used because the most recent version did not contain post-stratification weights. 
demographics and attitudes of respondents in European countries since 2002. The surveys represent some of the largest collections of individual-level data related to European political attitudes currently available and includes questions specifically about national level vote choice. ${ }^{2}$ Further, the longitudinal dimension of the study allows for researchers to track attitudinal changes over time. Since the ESS provides post-stratification weights (with design weights added) and country population size weights, all descriptive statistics and statistical modeling provided here incorporate the weights. In addition, all bivariate and multivariate statistical models are estimated using fixed effects modeling in order to account for the non-randomness that exists in the respondent's country. The statistical technique is useful since McEvoy (2016) concludes that there is significant cross-country variation in attitudes.

\subsection{Independent Variables}

There are a number of socio-demographic and attitudinal variables included in the empirical analysis as independent variables. ${ }^{3}$ First, a number of socio-demographics are included in order to determine whether the radical right was able to draw voters with distinct characteristics. These variables represent all of the basic socio-demographics that must be included in a study exploring vote choice: age, gender, education, income, employment status, and union membership. Previous empirical research on radical right voting has indicated that a few trends should emerge, albeit at different degrees of intensity. For instance, previous research confirms that voters for radical right parties tend to be men, older, less educated, unemployed, and in some instances

2 The radical right vote choice variable was created by coding vote choice in the European Social Survey from 2002-20I4. The survey is conducted every two years and asks which party the respondent voted for in the most recent national election. Notably, the survey is not conducted in every country for each year of the survey. Therefore, some radical right parties are only explored in specific time periods (e.g. Freedom Party - Austria). The variable is coded as a I if the respondent voted for the radical right party and a o if they voted for any other party. The parties coded as a radical right party vote choice are as follows: Freedom Party - Austria (2004-2006, 2014), Vlaams Blok - Belgium (2002-20I4), Danish People's Party - Denmark (2002-20I4), Ataka - Bulgaria (2006-20I4), Croatian Party of Rights - Croatia (20IO), Pro Patria Union - Estonia (2006-20I4) True Finns - Finland (2002-2OI4), National Front - France (2002-2OI4), National Democratic Party - Germany (2002-2014), Republican Party - Germany, (2002-2OI4), Alternative for Germany - Germany (2014), Jobbik - Hungary (2006-20I4), Golden Dawn - Greece (2010), Lega Nord - Italy (2002, 2012), National Front - Italy (2002, 2012), List Pim Fortuyn - Netherlands (2002-2004), Party for Freedom Netherlands (2004-2014), Progress Party - Norway (2002-20I4), Slovenian National Party - Slovenia (2002-2012), Slovak National Party - Slovakia (2006-20I0), Sweden Democrats - Sweden (201020I4), Swiss People's Party - Switzerland (2002-20I4).

3 Variable coding, descriptive statistics, and any statistical tests performed for creating the independent variables (i.e. Cronbachs Alpha scores, factor analysis, and binary correlation tests) are provided in the appendices. a member of a union (Kitschelt 1995, Givens 2005, Norris 2005, Mudde 2007).

The second set of variables included in the analysis is attitudinal variables. First, political ideology is included with the expectation that radical right voters will identify further right on the political spectrum than people that voted for other parties. Second, and perhaps more importantly, a measure is included for nativist attitudes (i.e. anti-immigrant attitudes). The variable was created through the use of factor analysis based on five questions about attitudes towards immigrants (see, Appendix B). Scholars have argued that many radical right parties are simply single-issue parties that draw voters based on anti-immigrant sentiment (van der Brug/Fennema/ Tillie 2000, Bos/van der Brug 2010). Therefore, a positive relationship is expected between anti-immigrant attitudes and radical right vote choice. Based on previous findings, it is expected that far right political ideology and anti-immigrant sentiment have the most direct relationship with radical right vote choice.

Third, a measure is included that attempts to capture anti-system behavior. Since there are no questions in the ESS that are capable of getting at useful conceptualizations of populism, distrust of governmental institutions is the most useful way of getting at skepticism towards elites and elite institutions. ${ }^{4}$ Fourth, there are two measures capturing attitudes that could be considered staunchly conservative or authoritarian: traditional beliefs and strong government (Givens 2005, Norris 2005, Mudde 2007). The traditional beliefs variable intends to measure the extent to which the respondent holds staunchly conservative attitudes, while the strong government variable intends to capture more authoritarian attitudes in relation to government control in society. Fifth, although the relationship between neoliberalism and radical right voting is debated in the literature, two variables are included in order to test whether a relationship exists. ${ }^{5}$ The first variable is specifically targeted at income and explores the respondent's agreement with the idea that the government should not reduce in-

4 Pauwels (2010) has undoubtedly demonstrated that many analyses utilizing survey data are unable to fully capture the complex nature of the concept of populism. For instance, Akkerman et al. (2014) and Hawkins and Rovira Kaltwasser (20I8) find that anti-elitism and populism are statistically two distinct sets of attitudes. The present study recognizes this difficulty and potential deficiency and attempts to use the only alternative means of measuring a broader idea of anti-system attitudes that are available.

5 As discussed previously, men tend to hold more rightist attitudes, which includes neoliberal attitudes. However, it is necessary to point out that the role that neoliberal attitudes play in radical right party policy or vote choice is debated in the literature. Some radical right parties, such as the Norwegian Progress Party, have put forth neoliberal policy platforms. However, many radical right parties do not espouse neoliberal policies. Due to the debate in the literature regarding the link between radical right parties and neoliberal attitudes, the variables are included here as attitudinal control variables. 
come disparity. The second variable is targeted at a broader notion of equality. In particular, the inclusion of this variable should indicate whether respondents that are less committed to the idea that people should all have equal opportunities are more likely to vote radical right. Finally, since some of the radical right parties have origins in the anti-European Union (EU) movement, a measure is included exploring whether distrust in the EU is associated with radical right vote choice.

\subsection{Dependent Variable \& Method}

The main dependent variable of interest in this study is radical right vote choice. The empirical analysis utilizes all available biennial data provided in the ESS from 200220I4. Overall, this research explores radical right vote choice for 22 parties in I8 European countries. Radical right vote choice in the samples ranges from a low of $6 \%$ in 2008-20I2 to a high of $8.8 \%$ in $2006 .{ }^{6}$ The debate over how to precisely categorize parties on the far right of the political spectrum has occurred in mass in the literature, ${ }^{7}$ and it is not the goal or intention of this research agenda to engage in the debate here. Therefore, only parties that a majority of the literature has classified as broadly radical right are included. Further, through factor analysis on policy positioning, Ennser (2OI2) found that the radical right party family is one of the most homogeneous party families. Therefore, there is less risk of including a political party that drastically skews the results. ${ }^{8}$

The empirical exploration proceeds in two stages. First, a bivariate analysis is conducted and bivariate mixed effects statistical models are estimated on variables of interest by gender. The reason for conducting a bivariate analysis is to get a basic sense of whether there are statistical differences between women and men on the socio-demographic and attitudinal variables that will be included in the multivariate analysis. Therefore, this first empirical investigation will provide an initial test for $H_{I}$, which hypothesizes that women and men

6 Radical right vote share in the samples was $7.7 \%$ in $2002,8 \%$ in $2004,8.8 \%$ in $2006,6 \%$ in $2008-2012$, and $8.4 \%$ in 2014 .

7 This study recognizes that there are differences between parties on the radical right of the ideological spectrum. For example, there are crucial differences between neo-nazi parties and Mudde's (2007) conceptualization of populist radical right parties. Indeed, important research has been conducted on classifying political parties on the right of the ideological spectrum (Van Kessel 2015, Huber/Ruth 2015, Huber/Schimpf 20I7). Therefore, several robustness checks were conducted in order to verify that an outlier party or a subset of political parties was not impacting the results

8 The potentiality for one party to skew the results is also drastically reduced due to the use of fixed effects models. In addition, several robustness checks were performed in order to verify that the results from the large-N fixed effects models aligned overwhelmingly with the results for individual country/party-level models. Finally, several models were estimated where individual countries/parties that could be considered outliers were excluded in order to verify the robustness of the results. The results were consistent with the results from the full sample. hold similar attitudes on those variables related to radical right vote choice. It should be noted that the mixed effects models take into account post-stratification and country population size weights.

Second, multivariate statistical models are estimated with all theoretically relevant independent variables. Since the dependent variable utilized in the multivariate analyses is binary, fixed effects binary regression models with clustered standard errors are estimated using post-stratification and country population size weights. When conducting the multivariate analysis, the independent variables are scaled to have a mean of one and a standard deviation of zero. The scaling of independent variables was done so that the variables could be on comparable scales in order to directly compare substantive effects in the statistical output. Further, the sample for the multivariate analysis is split by gender. The split samples mean that a fixed effects regression model will be estimated to predict radical right vote choice for women and men separately. By splitting the sample, it will be possible to explore two distinct trends. First, estimating separate regression models for women and men will allow us to view whether the same variables that predict radical right vote choice for women are also predictors for men. Second, by splitting the samples, it will be possible to calculate predicted probabilities in order to graph the substantive effect of statistically significant variables. Therefore, it will be possible to see whether an independent variable has a larger effect on one of the genders in regards to radical right vote choice. The modeling choice will allow for clearer results than a model with $\mathrm{I} 3$ interactions would provide. The multivariate analysis will allow for the direct testing of $\mathrm{H}_{2}$ and $\mathrm{H}_{3}$, which hypothesize that women and men are impacted by the same attitudes in terms of radical right vote choice, but the substantive effects of these attitudes will be smaller for women.

\section{Results}

\subsection{Fixed Effects Bivariate Models}

Table I displays a summary of the results from the bivariate fixed effects models conducted on the dependent variable (i.e. radical right vote choice) and independent variables that will be utilized in the multivariate analysis. The results from the models exploring the dependent variable demonstrate that women are statistically less likely than men to cast a vote for the radical right party across all years from 2002-2014. The result confirms findings from previous literature. In comparison, when dissecting the bivariate results for independent variables that generally predict radical right vote choice, results provide mixed support for previous findings. 
Table 1: Summary of Fixed Effects Bivariate Models: IV = Gender

\begin{tabular}{|c|c|c|c|c|c|c|c|c|}
\hline Variable & 2002 & 2004 & 2006 & 2008 & 2010 & 2012 & 2014 & Ful \\
\hline Radical Right Vote & - & - & - & - & - & - & - & - \\
\hline Age & & + & & + & & + & & + \\
\hline Education & & - & - & - & & & - & - \\
\hline Income & - & - & - & - & - & - & - & - \\
\hline Unemployed & & + & + & & + & & & + \\
\hline Union Member & - & - & - & - & - & - & - & - \\
\hline Political Ideology & - & - & - & - & - & - & - & - \\
\hline Nativist Attitudes & & & & & & - & & - \\
\hline Institutional Distrust & + & + & + & & & & + & + \\
\hline Traditional Beliefs & + & + & + & + & + & + & + & + \\
\hline Strong Government & + & + & + & + & + & + & + & + \\
\hline Gov. Not Reduce Disparity & + & + & + & + & + & + & + & + \\
\hline Anti-Equal Opportunities & - & - & - & - & - & - & - & - \\
\hline EU Distrust & - & & - & - & - & - & - & - \\
\hline
\end{tabular}

- indicates a negative statistically significant relationship $(p<0.05) . /+$ indicates a positive statistically significant relationship $(p<0.05)$.

First, women are unsurprisingly at lower levels on sociodemographic variables such as education, income and union membership. Men tend to be at higher income and education levels in the sample. In addition, men are more likely to be members of a trade union. On the other hand, where statistical difference exists, men are indeed more likely to be unemployed, which some scholars have argued is a large driver of radical right vote choice. Further, in terms of political attitudes, women are statistically more leftist in political ideology, have less distrust in the $\mathrm{EU}$, and are more likely to think that everyone should have equal opportunities. The results indicate that the gender gap in voting radical right could be explained by anti-EU sentiment, political ideology, or neoliberalism if one were to find in the multivariate analysis that these variables are important. The results align quite well with theoretical expectations regarding a basic gender gap in political ideology and radical attitudes.

On the other hand, the bivariate fixed effects model output indicates that women are statistically higher on a number of variables that are theoretically related to voting for a radical right party, which previous research has not uncovered. For example, women hold statistically higher levels of distrust towards institutions, commitment to traditions and traditional beliefs, belief in a strong government, and feelings that the government should not reduce income disparity. The results are somewhat surprising, but do not get us closer to understanding the gap in voting for radical right parties. Indeed, if these four attitudes were highly predictive of radical right vote choice one would expect that women have a higher propensity to vote for the party.

The main finding from the bivariate analyses conducted here is that women and men are rarely statistically different when it comes to anti-immigrant attitudes. Since several scholars have argued that radical right parties are simply anti-immigrant parties (Bos/ van der Brug 20I0, van der Brug/Fennema/Tillie 2000), the result that women and men are not statistically different in terms of their level of nativism is quite interesting. Further, when exploring Table I, what is unique about the bivariate analysis conducted on nativist attitudes is that women are only less likely to hold these attitudes in 2012, however, from 2002-2010 and in 2014 there is no statistical difference between the genders. When delving into the data further, the change in the statistical difference can be blamed on men. That is, while women have remained relatively the same in terms of nativist attitudes (just slightly nativist), men have on average become increasingly more nativist over the time period. The result aligns with previous research conducted in the United States, which demonstrated that men have become more conservative or right-wing on a number of important attitudinal positions (Kaufmann/ Petrocik 1999). Since the nativist attitudes measure was created through the use of factor analysis based on five attitudinal questions that asked about attitudes towards immigrants, it is worth checking whether any of the attitudes are driving the result. 
Table 2: Summary of Fixed Effects Bivariate Models for Nativist Features: IV=Gender

\begin{tabular}{|c|c|c|c|c|c|c|c|}
\hline Variable & 2002 & 2004 & 2006 & 2008 & 2010 & 2012 & 2014 \\
\hline $\begin{array}{l}\text { Allow many or few immigrants- different } \\
\text { ethnic group }\end{array}$ & - & - & & & & - & \\
\hline $\begin{array}{l}\text { Allow more or less immigrants - outside } \\
\text { Europe }\end{array}$ & - & - & & - & & - & - \\
\hline Immigrants good or bad for economy & + & + & + & + & + & + & + \\
\hline Immigrants enrich or damage culture life & - & - & - & - & - & - & - \\
\hline $\begin{array}{l}\text { Immigrants make country better or } \\
\text { worse place to live }\end{array}$ & & & & & - & & \\
\hline
\end{tabular}

- indicates that gender has a negative statistically significant relationship $(p<0.05) . /$ + indicates that gender has a positive statistically significant relationship $(p<0.05)$.

Variables coded so that higher values indicate anti-immigrant sentiment.

Table 2 displays the results from bivariate fixed effects models performed on the five survey questions utilized to create the nativist attitude measure with gender as the independent variable. ${ }^{9}$ Further, the Appendix B provides factor analysis output and Cronbach's Alpha Scores for the nativist indices for each year created from the five survey questions. As the results indicate, the creation of indices in the analysis is statistically appropriate. As Table 2 indicates, there are only really two instances where men are consistently statistically higher on an anti-immigrant measure. Men are on average more likely to think there should be fewer immigrants from outside Europe, and more likely to think that immigrants damage cultural life. On the other hand, there is one consistent question where women hold statistically more negative views of immigrants. From 2002-2014, women were statistically more likely to think that immigrants are bad for the economy. Given that the literature is fairly clear regarding women's averseness to voting for the radical right party, the result is interesting. ${ }^{10}$

On the other hand, there are no clear trends regarding believing that immigrants make the country a worse place to leave. In addition, from 2006-20IO and in 20I4, there is not a difference between men and women in regards to whether they believe that their country should only allow a few immigrants from different ethnic groups. If these parties mainly draw voters based on the issue of nativism, or anti-immigrant backlash, one would expect that women might cast votes for the party if they hold such attitudes. However, given the results in Table 2 this might not be the case. The multivariate analysis provides additional information on the role that nativist attitudes play in predicting radical right vote choice for women and men.

9 It is important to note that these variables correlated at .58 or higher. IO As an additional check, density plots for several variables of interest are presented in Appendix E. The density plots confirm that the distributions for women and men are very similar for several variables of interest.

\subsection{Multivariate Analysis}

The results from the multivariate fixed effects binary models are presented in Tables 3-5. Previous empirical findings present conflicting results relative to the relationship between demographic variables and radical right vote choice. What is important for the purpose of this study is that women and men generally follow the same trend, as indicated by the results below. Table 3 provides a summary of the findings from the multivariate models. The results indicate that in a given year, men and women follow similar trends. For example, from 2002-2014 age has a negative relationship with the probability of voting for a radical right party. Further, from 20IO-20I4, education is negatively related to radical right vote choice. Even where a socio-demographic does not maintain the same trend over time, we see that in a given time period men and women are affected by the variable in a similar way. For instance, between 2002-2006 union membership is negatively related to voting radical right, but from 20IO-2012 for both men and women, union membership is positively related.

In regards to attitudinal variables, similar trends exist. Women and men follow the same trends in terms of the relationship between the attitudinal variables and radical right vote choice. For example, both women and men show a positive relationship between political ideology and radical right vote choice. Further, where significant, authoritarian attitudes, conservative attitudes, and attitudes regarding inequality are, on average, positively related to radical right vote choice for women and men. The only situation in which conflicting results arise is with the institutional distrust measure, which as stated previously, is a very crude proxy for distrust of elites.

The only attitudinal variables that show a consistent relationship across all years and statistical models are political ideology and nativist attitudes. Both political ideology and nativist attitudes are positively correlated with casting a vote for the radical right party in all of the 
Table 3: Radical Right Vote Choice: Significant Coefficients - Fixed Effects Multivariate Models

\begin{tabular}{|c|c|c|c|c|c|c|c|c|c|c|c|c|c|c|}
\hline \multirow[t]{2}{*}{ Variable } & \multicolumn{2}{|c|}{2002} & \multicolumn{2}{|c|}{2004} & \multicolumn{2}{|c|}{2006} & \multicolumn{2}{|c|}{2008} & \multicolumn{2}{|c|}{2010} & \multicolumn{2}{|c|}{2012} & \multicolumn{2}{|c|}{2014} \\
\hline & W & M & W & M & W & M & W & $M$ & W & M & W & M & W & M \\
\hline Constant & - & - & - & - & - & - & - & - & - & - & - & - & - & - \\
\hline Age & - & & - & - & - & - & - & - & - & - & - & - & - & - \\
\hline Education & & & & & + & + & & & - & - & - & - & - & - \\
\hline Income & + & + & & + & + & + & & - & & & & & & + \\
\hline Unemployed & & - & & & & & & & & & & & & + \\
\hline Union Member & - & & - & & - & & & + & + & + & + & + & & \\
\hline Political Ideology & + & + & + & + & + & + & + & + & + & + & + & + & + & + \\
\hline Nativist Attitudes & + & + & + & + & + & + & + & + & + & + & + & + & + & + \\
\hline $\begin{array}{l}\text { Institutional } \\
\text { Distrust }\end{array}$ & & + & & + & & + & - & - & - & & & & & \\
\hline Traditional Beliefs & & - & + & & & & & + & & & & & & - \\
\hline Strong Government & & & & & + & + & & & & & & & & + \\
\hline $\begin{array}{l}\text { Gov. Not Reduce } \\
\text { Disparity }\end{array}$ & & & & + & & & & & & & & & + & \\
\hline $\begin{array}{l}\text { Anti-Equal } \\
\text { Opportunities }\end{array}$ & + & & + & + & & & + & & & + & & & + & \\
\hline EU Distrust & + & + & + & & & + & + & + & + & + & + & + & + & + \\
\hline
\end{tabular}

- indicates a negative statistically significant relationship $(p<0.05) . /+$ indicates a positive statistically significant relationship $(p<0.05)$.

instances tested. In addition, when exploring the standardized coefficients across statistical models, political ideology and nativist attitudes have the largest statistical relationship with the probability of voting for the radical right party than do any other variables in the multivariate models. In fact, over time the two variables tradeoff as the largest predictor of radical right vote choice in the multivariate models. The results from the model output provide evidence to support $H_{2}$. Mainly, that results indicate that for men and women the same attitudinal positions predict radical right party vote choice. As the literature has found, on the two variables of greatest importance, there is a statistical relationship between the attitudes and vote choice across all models for both men and women. In order to test hypothesis $H_{3}$, the relationships must be explored further in terms of the substantive impact that these variables play on the probability of voting radical right. Therefore, predicted probabilities are plotted for the political ideology and nativist variables while holding all continuous variables at their mean and dummy variables at zero for both genders. Figures I and 2 plot the substantive effect of political ideology and nativism on radical right vote choice for women and men.

Figures I and 2 provide a test for $H_{3}$, which hypothesized that the substantive effects from independent variables that increase the probability of voting for the radical right party are smaller for women than the substantive effects are for men. Remember, both variables are coded so that positive values indicate extremes closer to voting for the radical right. First, Figure I presents the substantive effect that nativist attitudes have on the probability of voting for the radical right party. On average, when going from the most positive attitudes towards immigrants to the most negative attitudes, men experience a higher increase in the probability of voting for the radical right party. Let us explore the most extreme difference as an example (i.e. effect of nativism on the probability of voting radical right in 2008). In 2008, for women, going from the most extreme positive attitudes towards immigrants to the most negative attitudes towards immigrants leads to an increase of around .05 $(5 \%)$ in the probability of voting for the radical right party. In comparison, for men, the change from one extreme attitudinal position to the other is an increase of about .I4 (I4\%) in the probability of voting for the radical right party. Here, the nativist variable's effect on men is almost three times higher than for women.

Figure 2 graphically presents the predicted probabilities for the effect of political ideology on radical right vote choice for men and women. In several instances, it is clear that the effect of far right positioning on the political ideology scale has a larger substantive effect on men in comparison to women. For example, in 2004, 
Table 4: Radical Right Vote Choice: Fixed Effects Models Output

\begin{tabular}{|c|c|c|c|c|c|c|c|c|}
\hline & \multicolumn{2}{|l|}{2002} & \multicolumn{2}{|l|}{2004} & \multicolumn{2}{|l|}{2006} & \multicolumn{2}{|l|}{2008} \\
\hline & Women & Men & Women & Men & Women & Men & Women & Men \\
\hline \multirow[t]{2}{*}{ (Intercept) } & $-3.03^{* * *}$ & $-2.83^{* * *}$ & $-2.96^{\star * *}$ & $-2.53^{\star \star \star}$ & $-2.64 * * *$ & $-2.35^{\star \star *}$ & $-3.10 * \star *$ & $-2.66^{\star * *}$ \\
\hline & $(0.09)$ & $(0.09)$ & $(0.09)$ & $(0.08)$ & $(0.08)$ & $(0.07)$ & $(0.10)$ & $(0.09)$ \\
\hline \multirow[t]{2}{*}{ Age } & $-0.27^{\star *}$ & -0.02 & $-0.18^{*}$ & $-0.19 *$ & $-0.20 * *$ & $-0.14^{*}$ & $-0.43^{* * *}$ & $-0.33^{* * *}$ \\
\hline & $(0.09)$ & $(0.07)$ & $(0.09)$ & $(0.07)$ & $(0.07)$ & $(0.06)$ & $(0.09)$ & $(0.07)$ \\
\hline \multirow[t]{2}{*}{ Education } & 0.03 & 0.03 & 0.10 & 0.06 & 0.20 ** & $0.18^{\star *}$ & -0.12 & -0.06 \\
\hline & $(0.08)$ & $(0.06)$ & $(0.07)$ & $(0.06)$ & $(0.07)$ & $(0.06)$ & $(0.09)$ & $(0.07)$ \\
\hline \multirow[t]{2}{*}{ Income } & $0.20^{*}$ & $0.27^{\star \star *}$ & 0.12 & $0.22^{* *}$ & $0.27^{* * *}$ & $0.16^{*}$ & -0.10 & $-0.17^{* *}$ \\
\hline & $(0.08)$ & $(0.07)$ & $(0.09)$ & $(0.07)$ & $(0.07)$ & $(0.07)$ & $(0.08)$ & $(0.06)$ \\
\hline \multirow[t]{2}{*}{ Unemployed } & -0.07 & $-0.12^{*}$ & -0.01 & 0.09 & 0.08 & 0.07 & 0.06 & -0.02 \\
\hline & $(0.07)$ & $(0.06)$ & $(0.07)$ & $(0.05)$ & $(0.06)$ & $(0.05)$ & $(0.07)$ & $(0.06)$ \\
\hline \multirow[t]{2}{*}{ Union Member } & $-0.27^{* * *}$ & 0.06 & $-0.20 * *$ & -0.03 & $-0.18^{\star *}$ & -0.03 & -0.00 & $0.15^{*}$ \\
\hline & $(0.07)$ & $(0.06)$ & $(0.07)$ & $(0.06)$ & $(0.06)$ & $(0.05)$ & $(0.07)$ & $(0.06)$ \\
\hline \multirow[t]{2}{*}{ Political Ideology } & $0.62^{* * *}$ & $0.66^{* * *}$ & $0.41^{* * *}$ & $0.63^{* * *}$ & $0.47^{* * *}$ & $0.57^{* * *}$ & $0.55^{* * *}$ & $0.68^{* * *}$ \\
\hline & $(0.08)$ & $(0.06)$ & $(0.08)$ & $(0.06)$ & $(0.06)$ & $(0.05)$ & $(0.08)$ & $(0.07)$ \\
\hline \multirow[t]{2}{*}{ Nativism } & $0.66^{* * *}$ & $0.70^{* * *}$ & $0.73^{* * *}$ & $0.74^{* * *}$ & $0.44^{* * *}$ & $046^{* * *}$ & $0.50^{* * *}$ & $0.68^{* * *}$ \\
\hline & $(0.09)$ & $(0.07)$ & $(0.09)$ & $(0.07)$ & $(0.07)$ & $(0.06)$ & $(0.09)$ & $(0.07)$ \\
\hline \multirow[t]{2}{*}{ Institutional Distrust } & 0.18 & $0.18^{*}$ & 0.12 & 0.22 & 0.17 & $0.26^{* * *}$ & $-0.32^{\star *}$ & $-0.16^{*}$ \\
\hline & $(0.09)$ & $(0.07)$ & $(0.10)$ & $(0.08)$ & $(0.09)$ & $(0.07)$ & $(0.11)$ & $(0.08)$ \\
\hline \multirow[t]{2}{*}{ Traditional Beliefs } & -0.01 & $-0.12^{*}$ & $0.16^{*}$ & 0.06 & 0.04 & -0.02 & 0.08 & $0.14^{*}$ \\
\hline & $(0.08)$ & $(0.06)$ & $(0.07)$ & $(0.06)$ & $(0.06)$ & $(0.05)$ & $(0.07)$ & $(0.06)$ \\
\hline \multirow[t]{2}{*}{ Strong Government } & 0.04 & 0.04 & 0.08 & 0.01 & $0.19^{* *}$ & $0.15^{\star *}$ & 0.12 & -0.00 \\
\hline & $(0.08)$ & $(0.06)$ & $(0.08)$ & $(0.06)$ & $(0.06)$ & $(0.05)$ & $(0.08)$ & $(0.06)$ \\
\hline \multirow{2}{*}{$\begin{array}{l}\text { Gov Reduce Income } \\
\text { Inequality }\end{array}$} & 0.05 & -0.02 & 0.01 & $0.22^{* * *}$ & -0.02 & -0.05 & -0.02 & -0.05 \\
\hline & $(0.07)$ & $(0.05)$ & $(0.05)$ & $(0.05)$ & $(0.06)$ & $(0.05)$ & $(0.07)$ & $(0.05)$ \\
\hline \multirow[t]{2}{*}{ Anti-Equal Opportunities } & $0.19^{* *}$ & 0.08 & $0.15^{*}$ & $0.16^{*}$ & 0.08 & 0.03 & $0.15^{*}$ & 0.02 \\
\hline & $(0.07)$ & $(0.05)$ & $(0.07)$ & $(0.05)$ & $(0.06)$ & $(0.05)$ & $(0.07)$ & $(0.06)$ \\
\hline \multirow[t]{2}{*}{ EU Distrust } & $0.25^{* *}$ & $0.19^{* *}$ & $0.30^{* *}$ & 0.08 & -0.07 & -0.01 & $0.68^{* * *}$ & $0.45^{* * *}$ \\
\hline & $(0.09)$ & $(0.07)$ & $(0.10)$ & $(0.08)$ & $(0.08)$ & $(0.06)$ & $(0.11)$ & $(0.08)$ \\
\hline $\mathrm{N}$ & 4230 & 4665 & 4347 & 4422 & 4543 & 4747 & 4885 & 4935 \\
\hline AIC & 1681.413 & 2495.403 & 1740.08 & 2424.252 & 2365.026 & 2970.978 & 1658.193 & 2395.475 \\
\hline Log Likelihood & -826.71 & -1233.70 & -856.04 & -1198.13 & -1168.51 & 1471.49 & -815.10 & -1183.74 \\
\hline
\end{tabular}

*** $p<0.001,{ }^{* *} p<0.01,{ }^{*} p<0.05$ 
Table 5: Radical Right Vote Choice: Fixed Effects Models Output

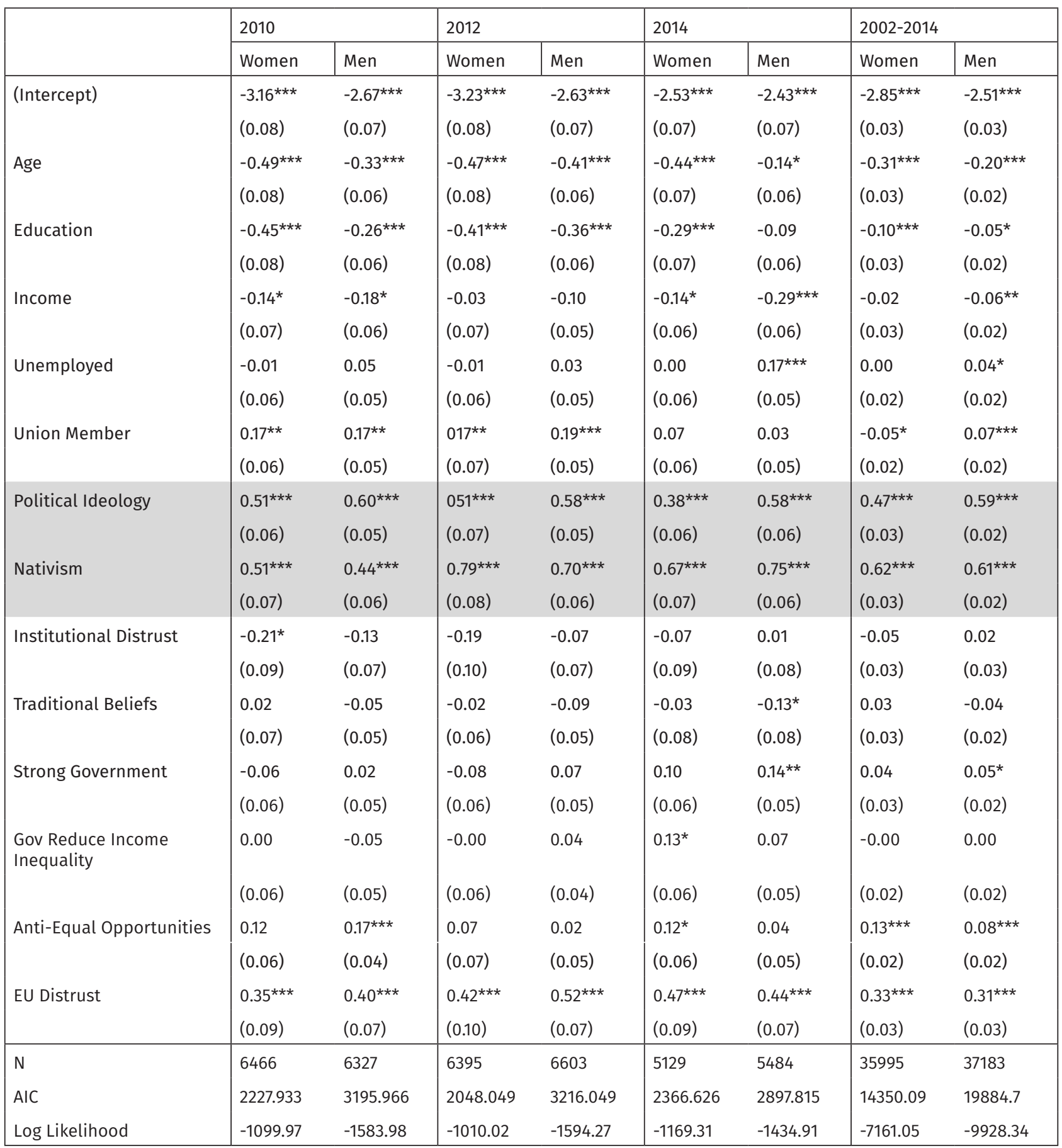

*** $p<0.001,{ }^{* *} p<0.01,{ }^{*} p<0.05$ 
12

M. A. Hansen: Women and the Radical Right I OZP Vol. 48, Issue 2

Figure 1: Predicted Probabilities: Nativist Attitudes on Radical Right Vote Choice
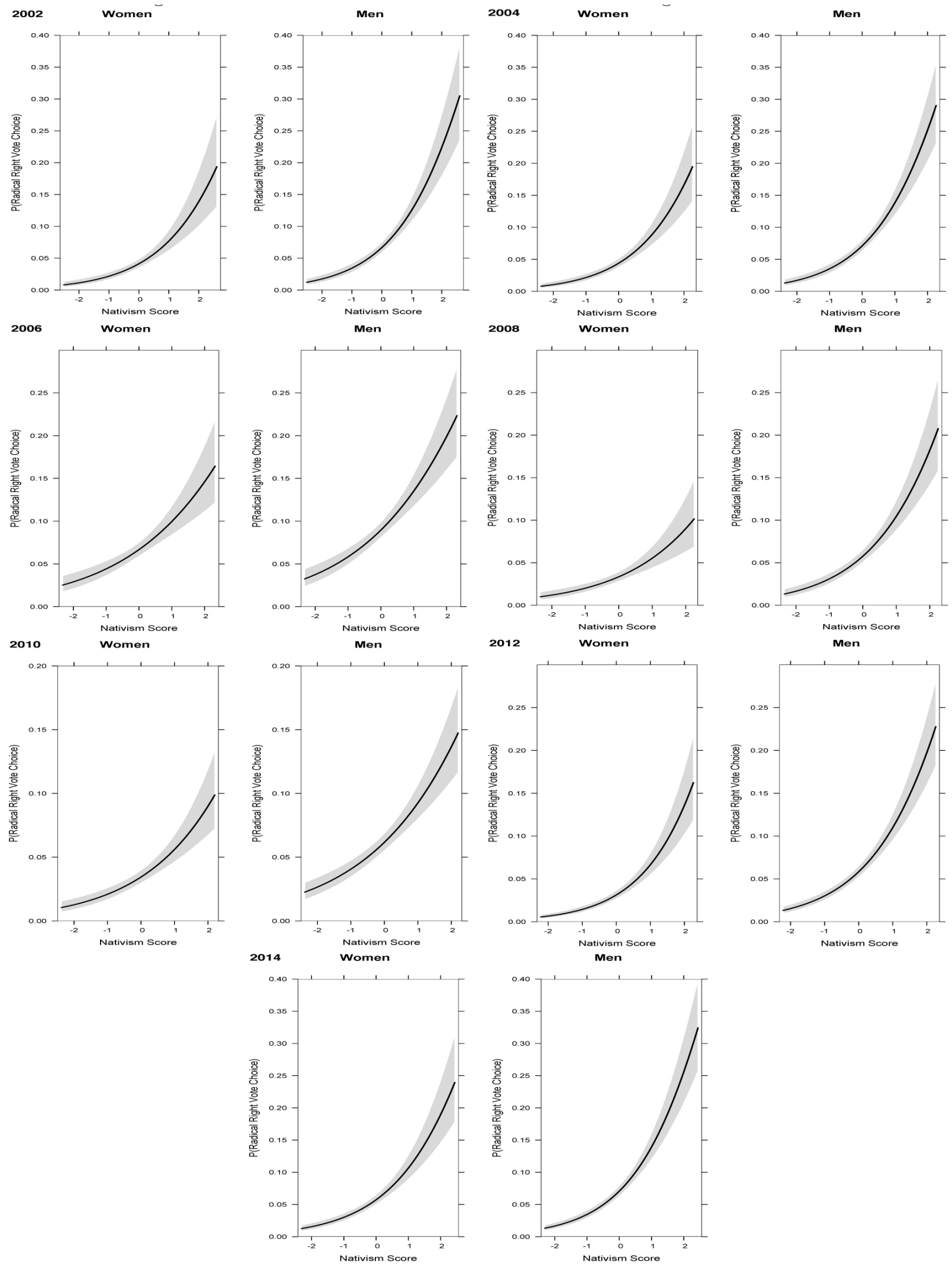
Figure 2: Predicted Probabilities: Political Ideology on Radical Right Vote Choice
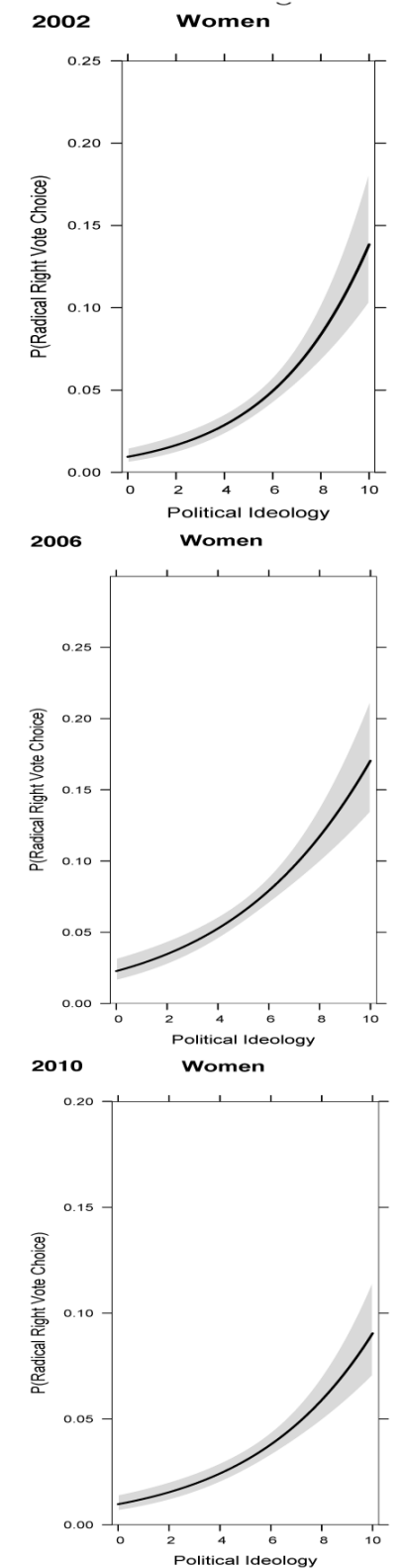

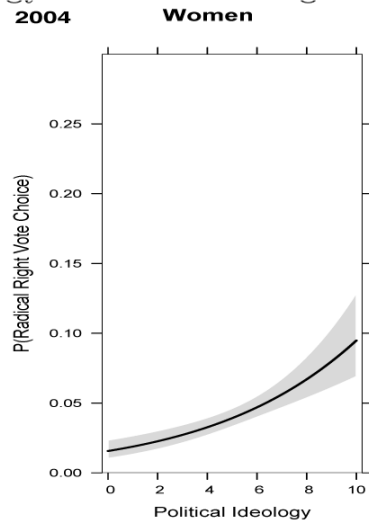

2008

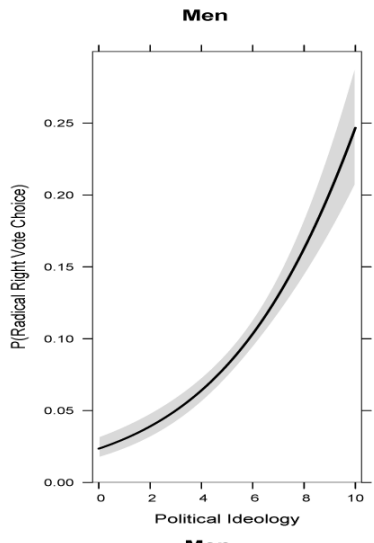

Men

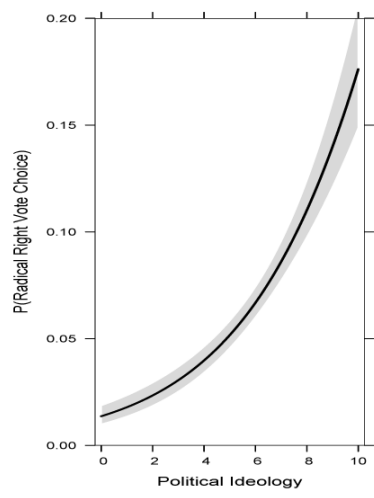

2014

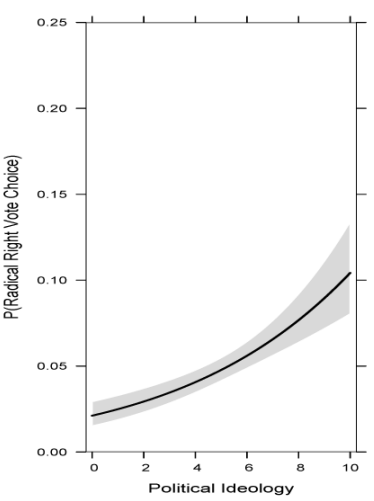

2012

Men

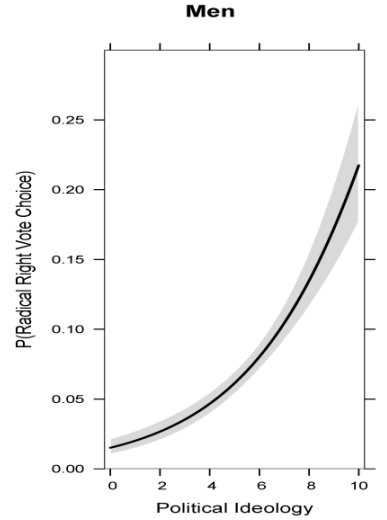

Men
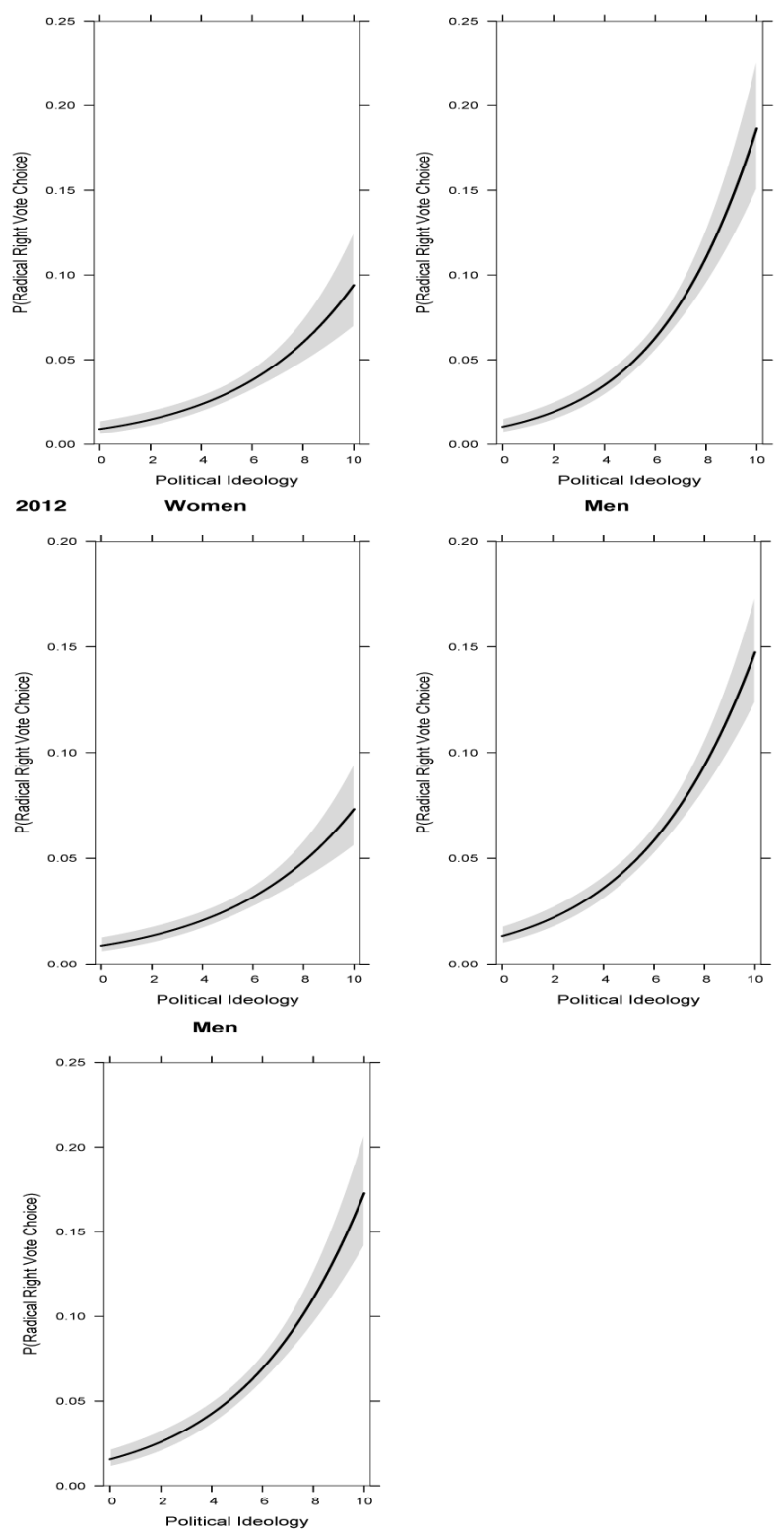
going from the furthest left position on the ideological spectrum to the furthest right position for women led to an increase of about .03 (3\%) in the probability of voting for the radical right party. On the other hand, the effect from the political ideology variable for men was about a . 15 ( $15 \%)$ increase in the probability of voting for the radical right party. Since the bivariate analysis indicates that men tend to me more ideological rightist, it would make sense that there would be a significant gender gap in voting for the radical right.

The results indicate that women and men are not equally affected by the attitudinal positions most associated with radical right voting. Indeed, across all models and statistically significant variables, there is a trend where the substantive effect of the variable is larger for men than for women. Clearly, women are substantially less likely to translate extreme positions on the ideological spectrum and anti-immigrant attitudes into a vote for the radical right party, despite holding similar attitudinal positions.

\section{Conclusion}

The empirical analysis conducted in this paper tested for radical right vote choice cross-nationally in Europe from 2002-20I4 by gender. To date, the analysis provides the most comprehensive time period and systematic analysis in which gendered dynamics of specifically radical right vote choice is explored in isolation from other parties. Through the estimation of fixed effects binary and multivariate statistical models, this article explored three hypotheses. The first hypothesis posited that, on average, women and men hold similar levels on attitudes that are historically correlated with radical right party voting. The second hypothesis posited that the attitudes that predict radical right vote choice for men are the same attitudes that predict radical right vote choice for women. Finally, the last hypothesis posited that, for women, the substantive effects from independent variables that increase the probability of voting for the radical right party are smaller than the substantive effects for men.

Based on the three posited hypotheses, the article arrives at a few conclusions. First, the results are mixed when exploring whether women and men statistically differ drastically when exploring the several attitudes that explain radical right vote choice. For example, previous research has demonstrated that anti-immigrant sentiment is one of the key attitudinal positions that drive radical right vote choice. Here, the finding is that women and men do not statistically differ in the level of anti-immigrant sentiment they hold. However, there is one crucial caveat to this finding. The results do indicate that a portion of the gender gap in radical right party voting can be explained by women's ideological positioning. Women are statistically less likely to selfposition themselves on the far right of the ideological spectrum. Since far right positioning is correlated with radical right vote choice, it is fairly clear that gendered differences on this variable of interest explain some of the variation in vote choice.

Second, the same political attitudes that predict radical right vote choice for men also predict radical right vote choice for women. Further, the relative importance of the political attitudes in predicting vote choice when comparing the substantive impact of the independent variables follow the same patterns for men and women. For example, for both genders, political ideology and nativist attitudes play the largest role in determining radical right vote choice when compared to any other attitudes or socio-demographic variables. The finding is useful for indicating that men and women's vote choice for the radical right party can be explained by the same mechanisms: far-right positioning and hostility to immigrants.

Finally, the major takeaway from the paper is that the substantive impacts of the attitudes most closely related to radical right vote choice are larger for men when compared to women. That is, men are more likely to translate an extreme right positioning or anti-immigrant attitudes into actual radical vote choice. When comparing women and men, both on the far right of the political spectrum holding the same level of hostility towards immigrants, the predicted probability of voting for a radical right party will be statistically much higher for men. The result arises even when holding all other variables at the same values for men and women, which has not been done in previous research. This analysis is the first to empirically test the differing substantive effects on men and women that attitudes have on voting for the radical right.

What is the next step for research on the gender gap in radical right voting? As Akkerman et al. (2014) have demonstrated, existing cross-national surveys do not measure the concept of populism effectively. Instead, large- $\mathrm{N}$ studies are better equipped for measuring antielitism. Further, Akkerman et al. (2014) and Hawkins and Rovira Kaltwasser (2018) argue there are important substantive differences between populism and antielitism. Since Van Hauwaert and Van Kessel (2018) find broadly that populist attitudes can be important for explaining vote choice, future research on the gender gap in radical right voting should more deeply explore the concept of populism, which includes more accurately measuring the concept in the gender gap research. 


\section{References}

Akkerman, Agnes/Cas Mudde/Andrea Zaslove (2014), How Populist Are the People? Measuring Populist Attitudes in Voters', in: Comparative Political Studies, Vol. 47 (9), I324-I353.

Bale, Tim/ Christoffer Green-Pedersen/ Andre Krouwel/ Kurt Richard Luther/Nick Sitter (2010), If You Cant Beat Them, Join Them? Explaining Social Democratic Responses to the Challenge from the Populist Radical Right in Western Europe, in: Political Studies, Vol. 58, 4IO-426.

Bos, Linda/W. van der Brug (2010), Public images of leaders of anti-immigration parties: Perceptions of legitimacy and effectiveness, in: Party Politics, Vol. I6 (6), 777-799.

Coffe, Hilde (2013), Gender, class, and radical right voting, in: Class Politics and the Radical Right, Jens Rydgren (ed.), New York: Taylor and Francis Group.

Ennser, Laurenz (2012), The homogeneity of West European Party Families: The Radical Right in Comparative Perspective, in: Party Politics, Vol. I8 (2), I5I-I7 I.

Erzeel, Silvia/Ekaterina R. Rashkova (2017), Still men's parties? Gender and the radical right in comparative perspective, in: West European Politics, Vol. 40 (4), 812820.

ESS Rounds I-6: European Social Survey (2017), Norwegian Centre for Research Data, Norway - Data Archive and distributor of ESS data for ESS ERIC.

Givens, Terri E. (2005), Voting Radical Right in Western Europe, Cambridge: Cambridge University Press.

Golder, Matt (2003), Explaining Variation In The Success of Extreme Right Parties in Western Europe, in: Comparative Political Studies, Vol. 36 (4), 432-466.

Hansen, Michael A. (2016), Voting Radical Right in Europe: A Comprehensive Explanation for Vote Choice, UW- Milwaukee, Theses and Dissertations, Paper II 48 .

Hansen, Michael A. and Jennifer L. Clemens (2018), What to expect when you're electing: the relationship between far-right strength and citizenship policy in Europe, in: Comparative European Politics, (Online First), I-23.

Harteveld, Eelco/Elisabeth Ivarsflaten (2016), Why Women Avoid the Radical Right: Internalized Norms and Party Reputations, in: British Journal of Political Science, Vol. 48 (2), 369-384.

Harteveld, Eelco/Stefan Dahlberg/Andrej Kokkonen/Wouter Van Der Brug (2017), Gender Differences in Vote Choice: Social Cues and Social Harmony as Heuristics, in: British Journal of Political Science, (First View), I-2I.

Harteveld, Eelco/Wouter Van Der Brug/Stefan Dahlberg/ Andrej Kokkonen (2015), The gender gap in populist radical right voting: examining the demand side in
Western and Eastern Europe, in: Patterns of Prejudice, Vol. 49(I-2), IO3-I34.

Hawkins, Kirk A./Cristóbal Rovira Kaltwasser (20I7), The Ideational Approach to Politics, in: Latin American Research Review, Vol. 52 (4), I-I6.

Howard, Marc Morje (20I0), The Impact of the Far Right on Citizenship Policy in Europe: Explaining Continuity and Change, in: Journal of Ethnic and Migration Studies, Vol. 36 (5), 735-75I.

Howell, Susan E./Christine L. Day (2000), Complexities of the Gender Gap, in: Journal of Politics, Vol. 62 (3), 858-874.

Huber, Robert A./Saskia P. Ruth (2017), Mind the Gap! Populism, Participation, and Representation in Europe, in: Swiss Political Science Review, Vol. 23 (4), 462484 .

Huber, Robert A./Christian H. Schimpf (20I7), On the Distinct Effects of Left-Wing and Right Wing Populism in Democratic Quality, in: Politics and Governance, Vol. $5(4), \mathrm{I} 46-\mathrm{I} 65$.

Immerzeel, Tim/Hilde Coffe/Tanja van der Lippe (2015), Explaining the gender gap in radical right voting: A cross-national investigation in I2 Western European countries, in: Comparative European Politics, Vol. I3 (2), 263-286.

Inglehart, Ronald/Pippa Norris (2000), The Developmental Theory of the Gender Gap: Women's and Men's Voting Behavior in Global Perspective, in: International Political Science Review, Vol. 2 I (4), 44I-463.

Ivarsflaten, Elisabeth/Scott Blinder/Robert Ford (2010), The Anti-Racism Norm in Western European Immigration Politics: Why we Need to Consider it and How to Measure it, in: Journal of Elections, Public Opinion and Parties, Vol. 20 (4), 42 I-445.

Kaufmann, Karen M. (2004), The Partisan Paradox: Religious Commitment and the Gender Gap in Party Identification, in: Pubic Opinion Quarterly, Vol. 68 (4), 49I-5II.

Kaufmann, Karen M./John R. Petrocik (1999), The Changing Politics of American Men: Understanding the Sources of the Gender Gap, in: American Journal of Political Science, Vol. 43 (3), 864-887.

Kellstedt, Paul M./David A. M. Peterson/Mark D. Ramirez (20IO), The Macro Politics of a Gender Gap, in: Public Opinion Quarterly, Vol. 74 (3), 477-498.

Kitschelt, Herbert (1995) The Radical Right in Western Europe, Ann Arbor: University of Michigan Press.

Mayer, Nonna (2015). The closing of the radical right gender gap in France?, in: French Politics, Vol. I3 (4), 39I-4I4.

McEvoy, Caroline (2016), Does the Descriptive Representation of Women Matter? A Comparison of Gendered Differences in Political Attitudes between Voters and Representatives in the European Parliament, in: Politics \& Gender, Vol. I2, 754-780. 
Meguid, Bonnie (2005), Competition Between Unequals: The Role of Mainstream Party Strategy in Niche Party Success, in: American Political Science Review, Vol. 99 (3), 347-359.

Mudde, Cas (2007), Populist Radical Right Parties in Europe, Cambridge: Cambridge University Press.

Norrander, Barbara/Clyde Wilcox (2008), The Gender Gap in Ideology, in: Political Behavior, Vol. 30 (4), 503523.

Norris, Pippa (2005), Radical Right: Voters and Parties in the Electoral Market, Cambridge: Cambridge University Press.

Pauwels, Teun (2010), Explaining the Success of NeoLiberal Populist Parties: The Case of Lijst Dedecker in Belgium, in: Political Studies, Vol. 58, I009-IO29.

Regan, Patrick M./Aida Paskeviciute (2003), Women's Access to Politics and Peaceful States, in: Journal of Peace Research, Vol. 4O (3), 287-302.

Schlesiger, Mark/Caroline Heldman (200I), Gender Gap or Gender Gaps? New Perspectives on Support for Government Action and Policies, in: Journal of Politics, Vol. 63 (I), 59-92.

Spierings, Niels/Andrej Zaslove (2015), Gendering the vote for populist radical-right parties, in: Patterns of Prejudice, Vol. 49 (I-2), I35-I62.

Spierings, Niels/Andrej Zaslove (2017), Gender, populist attitudes, and voting: explaining the gender gap in voting for populist radical right and populist radical left parties, in: West European Politics, Vol. 40 (4), 82 I847 .

van der Brug, Wouter/Meindert Fennema/Jean Tillie(2000), Anti-immigrant parties in Europe: Ideological or protest vote?, in: European Journal of Political Research, Vol. 37, 77-IO2.

Van Hauwaert, Steven M./Stijn Van Kessel (2018), Beyond protest and discontent: A cross-national analysis of the effect of populist attitudes and issue positions on populist party support, in: European Journal of Political Research, Vol. 57 (I), 68-92.

Van Kessel, Stijn (2015), Populist Parties in Europe: Agents of Discontent?, New York: Palgrave Macmillan.

van Spanje, Joost (2010), Parties beyond the pale: Why some political parties are ostracized by their competitors while others are not, in: Comparative European Politics, Vol. 8 (3), 354-383.

\section{Author}

Michael A. Hansen (corresponding author) is an assistant professor in the Department of Political Science at the University of Wisconsin - Parkside. His research focuses on parties of the radical right and political behavior in the U.S. and Europe.

\section{Supplemental Appendices}

\section{Appendix A: Variable Coding}

Socio-demographics: Age - respondent age at the time of the survey; Gender - o = male respondent, $\mathrm{I}=$ female respondent; Education - a weighted scale from $\mathrm{O}=$ Not Completed ISCED level I to $27=$ Master's degree or higher; Income - household's total net income, basic decile measurement from I to Io; Unemployed - any period of unemployment in the last I 2 months, $\mathrm{O}=$ not unemployed, I = period of unemployment; Union Member - $\mathrm{O}=$ not a member of a union, $\mathrm{I}=$ currently or previously a union member.

Political Attitudes: Political Ideology - The respondent is asked to self-place their ideology on a o (left) to Io (right) scale; Anti-Immigrant Sentiment - The anti-immigrant sentiment variable is created by estimating factors analysis based on three statements. The Cronbach's Alpha score for the three variables was on average .75 or higher. The proportion of the variance explained with one factor loading was on average around 0.550 . There were two statements that asked whether the respondent believes that many or few immigrants from either different ethnic groups or outside of Europe should be allowed to live in the country. The choices the respondent could select from were, $\mathrm{O}=$ allow many to come live here, $\mathrm{I}=$ allow some, 2 = allow a few, 3 = allow none. There were also three statements that asked a) whether immigrants are good or bad for the economy, b) whether immigrants enrich or damage cultural life, and c) whether immigrants make the country better or worse place to live. The variables were coded from -5 (most positive view of immigrants) to 5 (most negative view of immigrants); Institutional Distrust - The measure is created by estimating factor analysis on distrust in four political institutions (i.e. politicians, political parties, country's parliament, and legal system). The variables were coded from $-5=$ completed trust to $5=$ completed distrust. The Cronbach's Alpha score for the three variables was on average .85 or higher. The proportion of the variance explained with one factor loading was on average around 0.650.; Traditional Beliefs - The respondent is asked their level of agreement with the statement, "it is important to follow customs handed down from religion or family", o = disagree strongly - 5 = agree strongly; Strong Government - The respondent is asked their level of agreement with the statement, "it is important that government ensures safety against all threats and the state is strong to defend its citizens", o = disagree strongly - 5 = agree strongly; Gov. Not Reduce Disparity - The respondent is asked their level of agreement with the statement, "government should take measures to reduce differences in income levels", o 


\section{Appendix B: Descriptive Statistics and Factor Analysis - Full Sample}

Table B1: Descriptive Statistics: Mean Values by Gender (Full Sample: 2002-2014)

\begin{tabular}{lcc}
\hline & Women & Men \\
\hline Radical Right Vote & $6.13 \%$ & $9.36 \%^{*}$ \\
Demographics & & \\
Age & $50.63(16.39)$ & $50.77(16.34)$ \\
Education & $14.15(8.47)$ & $14.64(8.26)^{*}$ \\
Income & $6.13(2.67)$ & $6.57(2.6)^{*}$ \\
Unemployed & $0.27(0.44)$ & $0.25(0.43)^{*}$ \\
Union Member & $0.53(0.50)$ & $0.58(0.49)^{*}$ \\
& & \\
Attitudes & & $5.26(2.23)$ \\
Political Ideology & & $-0.20(0.91)$ \\
Nativist Attitudes & $5.00(2.17)$ & $-0.43(0.92)^{*}$ \\
Institutional Distrust & $-0.21(0.91)$ & $3.08(1.35)^{*}$ \\
Traditional Beliefs & $-0.36(0.89)$ & $3.41(1.24)^{*}$ \\
Strong Government & $3.30(1.32)$ & $3.61(1.14)^{*}$ \\
Gov. Not Reduce Income Disparity & $3.49(1.21)$ & $1.13(1.04)^{*}$ \\
Anti-Equal Opportunities & $3.83(1.04)$ & $0.40(2.27)^{*}$ \\
EU Distrust & $0.96(0.97)$ & $0.22(2.16)$ \\
\hline
\end{tabular}

Table B2: Factor Analysis Output and Cronbach's Alpha Scores: Nativist Measure

\begin{tabular}{|c|c|c|c|c|c|c|c|}
\hline Variable & 2002 & 2004 & 2006 & 2008 & 2010 & 2012 & 2014 \\
\hline $\begin{array}{l}\text { Allow many or few immigrants- different } \\
\text { ethnic group }\end{array}$ & 0.895 & 0.771 & 0.766 & 0.752 & 0.771 & 0.768 & 0.772 \\
\hline $\begin{array}{l}\text { Allow more or less immigrants - outside } \\
\text { Europe }\end{array}$ & 0.881 & 0.744 & 0.740 & 0.723 & 0.744 & 0.733 & 0.750 \\
\hline Immigrants good or bad for economy & 0.553 & 0.740 & 0.726 & 0.766 & 0.781 & 0.770 & 0.757 \\
\hline Immigrants enrich or damage culture life & 0.573 & 0.759 & 0.746 & 0.768 & 0.786 & 0.770 & 0.771 \\
\hline $\begin{array}{l}\text { Immigrants make country better or } \\
\text { worse place to live }\end{array}$ & 0.589 & 0.785 & 0.776 & 0.790 & 0.802 & 0.793 & 0.798 \\
\hline SS Loadings & 2.559 & 2.886 & 2.821 & 2.89 & 3.021 & 2.941 & 2.963 \\
\hline Proportion Variance & 0.512 & 0.577 & 0.564 & 0.578 & 0.604 & 0.588 & 0.593 \\
\hline
\end{tabular}

Estimated using post-stratification and population weights. 


\section{Appendix C: Effects Plots}

Figure C1: Predicted Probabilities: European Union Distrust
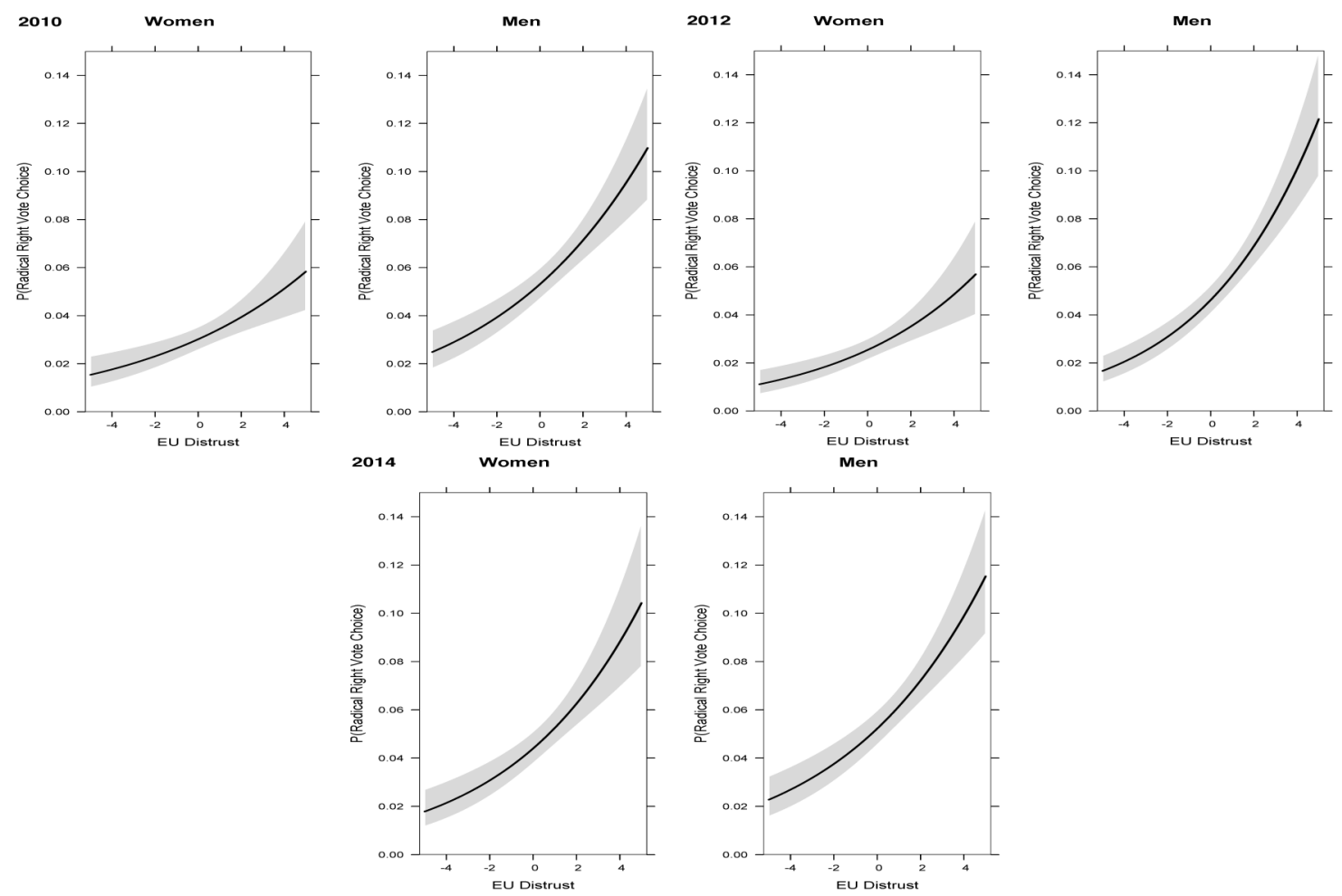
Appendix D: Density Plots

Figure D1: Density Plots for Political Ideology
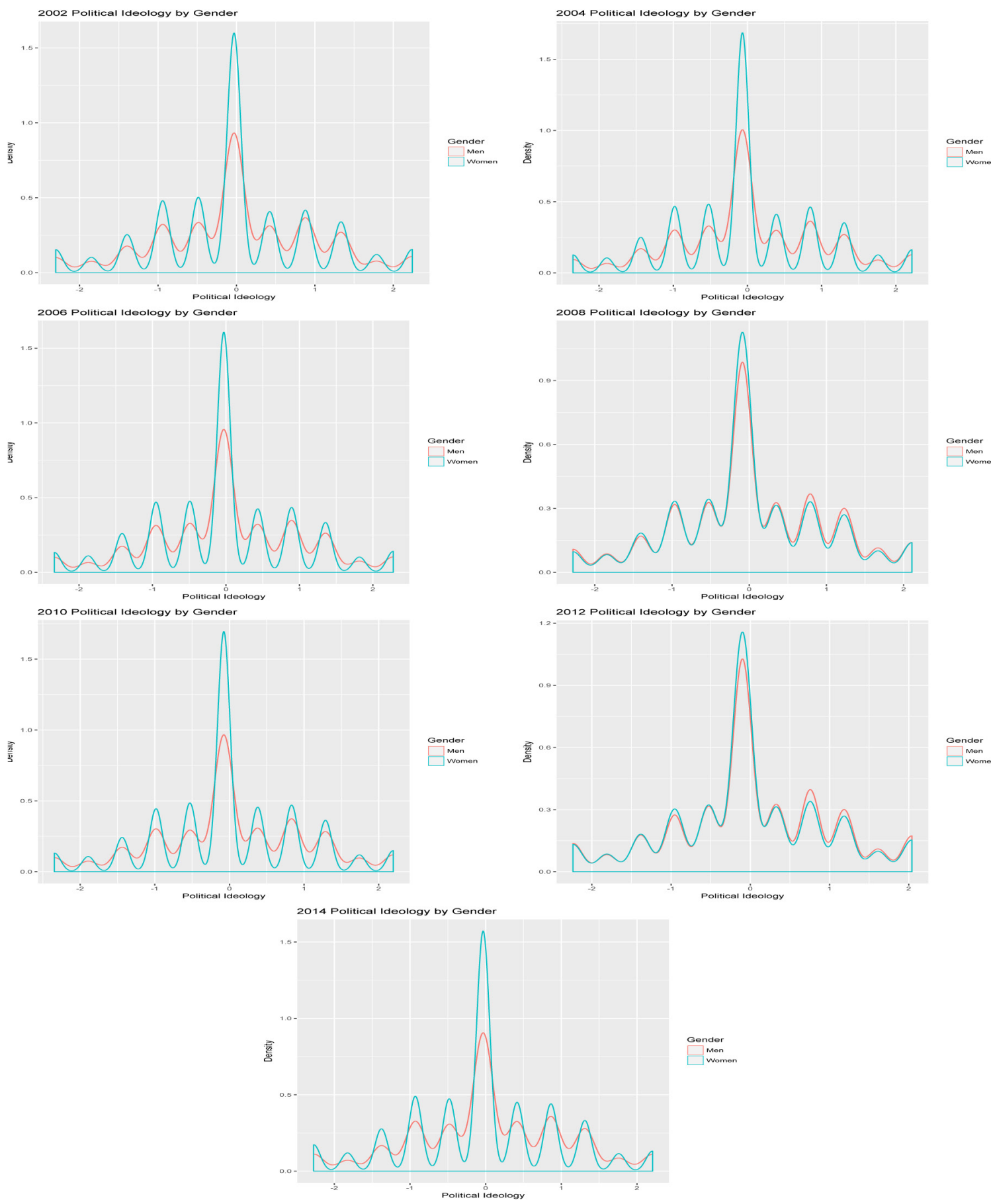
Figure D2: Density Plots for Nativist Attitudes
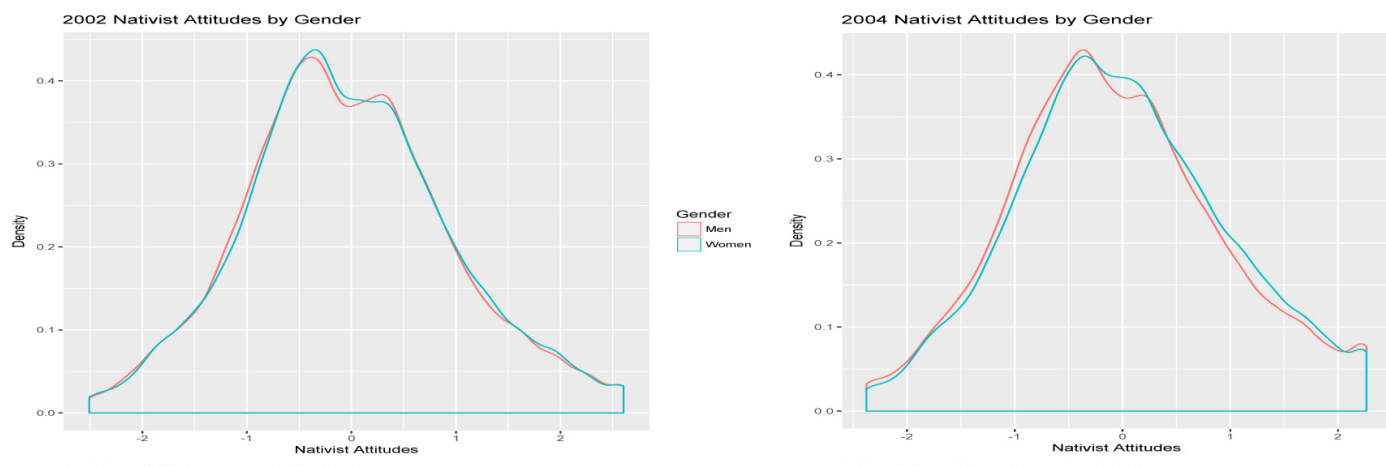

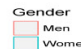
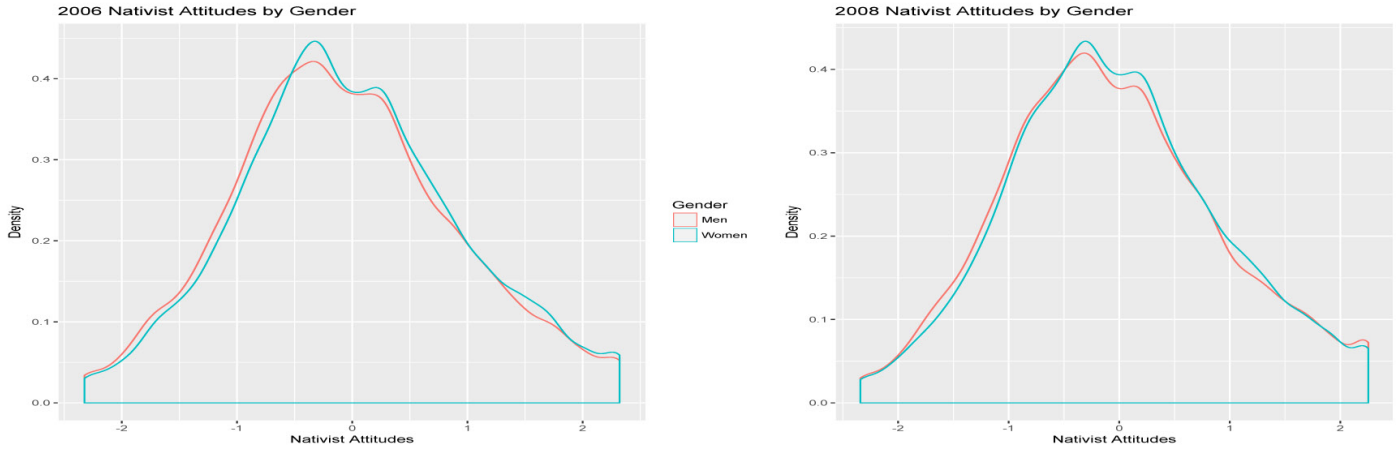

Gender
Mon
Mome
wome
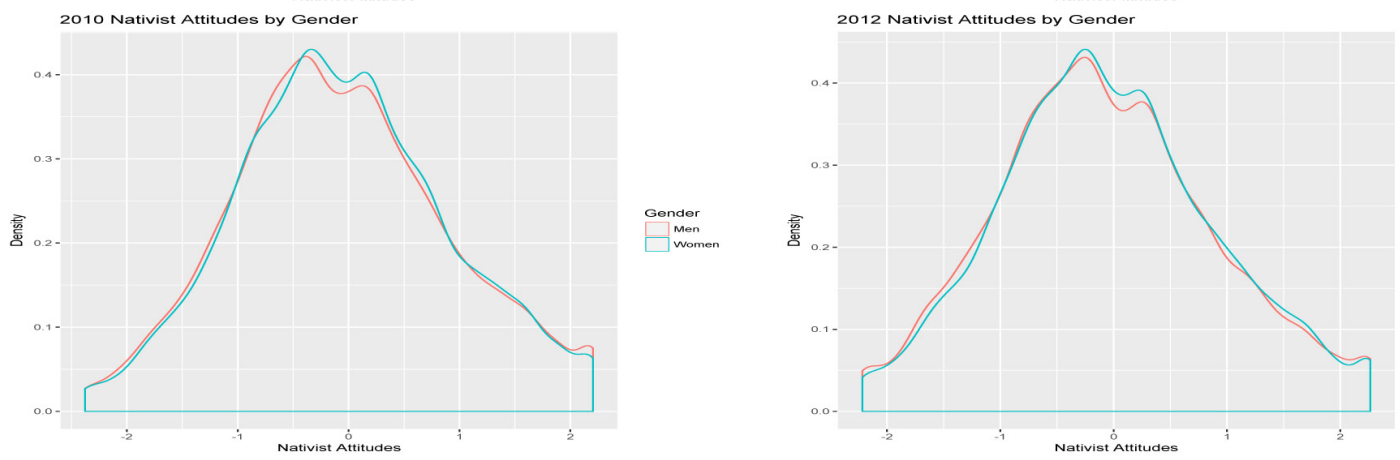

Gender
Man
Mome

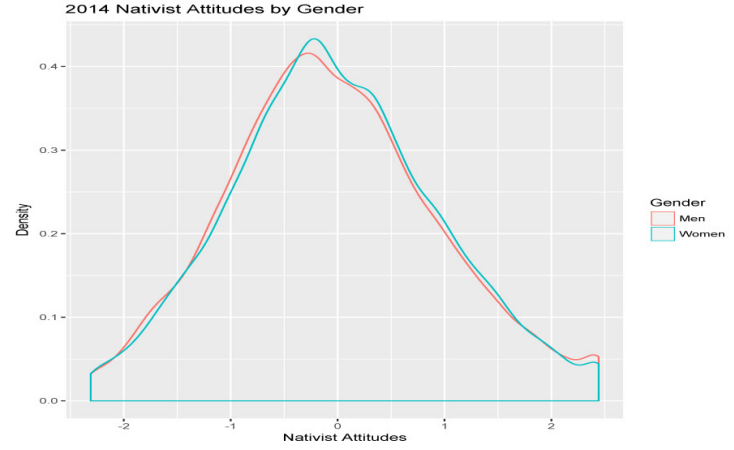




\section{Appendix E: Additional Variables}

There were a number of variables tested or included in the original multivariate analysis that were excluded in the final analysis for one of two reasons. First, some variables were excluded due to a high correlation with other; more theoretically grounded independent variables of interest. Second, a few variables were excluded after it was determined that there was not a significant or substantive relationship with the dependent variables of interest due to degrees of freedom limitations. For example, the original analysis explored feelings of being unsafe, dissatisfaction with the economy, dissatisfaction with democracy, and skepticism towards further European Union unification. 
